\title{
A Research on the Practice of Volunteer Guardianship in Primary Schools (Example of Trabzon Province)
}

\author{
Rıdvan Küçükali \\ Ataturk University, Faculty of Letters, Turkey
}

Copyright $(\mathrm{C} 2017$ by authors, all rights reserved. Authors agree that this article remains permanently open access under the terms of the Creative Commons Attribution License 4.0 International License

\begin{abstract}
In this study, we tried to find an answer to the question as to whether positive outcomes in socio-emotional and academic sense may be provided to the education of kids kept under the practice known as "Volunteer Guardians on duty". This study reached the following conclusions through the data obtained. The presence of legal guardians (parents) in schools that is one of the key stakeholders in education, their becoming familiar with the school, getting to know the school's problems, gaining the sense of ownership of the school will make a significant contribution to the students' academic, social, emotional and moral development. In this way, parents are required to take their responsibility regarding the school which includes for them to take ownership in the education process, thus increasing educational success. This work will contribute to future works as it represents a new application in Turkey. As a result of this study, positive increases in student and school effectiveness were observed.
\end{abstract}

Keywords Education, School Management, Volunteer Guardian, Educational Planning

\section{Introduction}

Communities and organizations constantly try to renew and improve themselves in terms of knowledge to sustain their existence. In this context, communities and organizations should restructure themselves in light of developments which have emerged, adapt to changes, make their work and working life more open to learning and include organizational learning as much as individual learning. That's why schools as learning organizations, teachers who bring schools to this dimension and parents who send students to be trained in schools all play an important role in this change and development. However, productivity in education and training activities can only be provided with the combined contributions of school, teachers, students and parents. In order to foster children's development, parents could provide various resources, such as occupational experiences, entertainment, and volunteer work. [1] For children's development, a lot of schools host open houses or back to school nights, providing tutoring services for parents, forming parent-teacher committees and parent-volunteer groups [2].

It is not an easy task to recognize, understand and educate people. School is one of the most important places where this work is done. In order to play their roles effectively in school, all the members of the school community should be involved, follow each other's roles and create the most harmonious environments, circumstances and situations for the kids. It is necessary for each player to display the appropriate words and behaviors on stage, to provide and facilitate the inputs and outputs of other players, and to be as close as possible to each other's roles. In order to ensure the necessary co-existence in this synergy, it is necessary for them to come together from time to time to cooperate [3]. In Turkey, the most important duties in the activity areas of schools are entrusted to the peoples other than the legal guardians. We have very strong sanction powers over the guardians. The parents do not participate adequately in the activity areas of the schools. The attendance rate at the PTA meetings is about $17 \%$. Whereas it is noticed that parents who have students in lower classes come to their kid's school more often, this ratio is decreased or lower for the parents of students in the upper classes. Generally, parents do come to the school during the registration of their children and never come again to the schools after that. It is expected that all the elements that are effective on the student gather together, take joint decisions and communicate with each other in the direction of the students in order to increase the education quality. The only fact that the student is in school is sometimes insufficient in terms of education and training.

In this context, West has performed a study to show how effective parents are in the extra-curricular activities of students. In this study, it was aimed to increase the family participation, family interest and presence, partially or continuously, and to create a comfortable information-supported environment in order to support the efforts of students and teachers. That being said, it has been 
observed that students who are not interested by their parents do not pay close attention to the lessons, usually do not do homework, or even do not know much about the homework given. It has also been observed that regarding students who were careless or uninterested in school and failed to attend, their parents were unconcerned about the failure reports sent to them. Besides, it was shown that they did not make any attempt to solve the indifference problems that their children faced with the lessons and the school and that at least as much as their children, did not give importance (care about) to their education [4].

If the family does not care about the child's education and does not intervene, classes will be ignored by the student and then he/she will not understand the importance and seriousness of education and training. The teachers and parents should try to determine individual needs of students, such as mobility, effective communication and managing inappropriate behaviors [5]. For this reason, education and training should involve a process that should include a teacher-student-parent cooperation.

The six main effective working program characteristics to build family partnership are mentioned below as defined in the study carried out by Epstein et al [6].

1 Child raising by their parents

2 Communication

3 Volunteering

4 Home learning

5 Decision making

6 Being in close cooperation with society

It is also recommended that schools follow the implementation process in five steps.

1 Create an action team;

2 Get resources and other support

3 Define the start

4 Develop a three-year plan and

5 Continue planning and working to develop the program.

It was found that the desired parenting program guidelines are implemented together with the components of these elements. Within the scope of this research, necessary information and studies have been put into practice. If pupils learn that their parents are interested in school-related activities and play an active role, it is very likely that academic success will be achieved. The child who realizes the interest of his / her family is now more self-confident, more attentive, active and effective; thus, he will be interested in taking care of his family attention and knowing that he is next to his family will make him gain self-confidence, and he will do his best to make them proud in order not to waste their effort and interest.

In a study by Hara and Burke, positive behaviors observed in pupils were revealed when parents were involved in the education of children. In that study, the following findings were obtained. With the participation of the parents in the education process of the children, many positive behaviors both in the parents and the child have emerged and the grounds for consolidation of these behaviors have been established. In this context, parents asked to talk more often to teachers with notes or through phone calls. Teachers have increased opportunities for individual communication among themselves. Parents and teachers have therefore increased the support they had for each other in understanding problem-solving opportunities and instructional strategies. They helped raise the quality of children's homework [7].

It is not enough for school administrators, teachers and students to take part in this activity. Schools should not aim to benefit only of parents' financial means but also from their skills as well. A lone musician may be able to teach students a music course or a language-skilled parent should be allowed to teach students that language in school. As long as the parents are not allowed to come to schools, they will not know the problems of the school, they will avoid the school by giving some excuses, and this will reduce the overall effectiveness of the school. However, their children are being trained in these schools. It will be much easier to catch up with changes and innovations in a school with increased effectiveness.

Moreover, thanks to these parents, the elimination of adverse events in the school entrance and exit will be possible. The presence of the legal guardians in the school will greatly prevent malicious people from approaching there. Security forces take necessary precautions at the entrance and exit of schools. However, since the security forces and the school administration can not recognize the environment as much as it really is, the necessary intervention is made only at the time of an incident. Because of guardians' better knowledge and their ability to better recognize the environment the school is in, they will be able to take precautionary measures by informing the security forces ahead of time by identifying the bad guys.

One aim of the schools is to provide communication between the environment, administrators, teachers, students and parents. At this point, all elements will be aware of one another and will know each other better. If mutual needs and deficiencies are not identified, organizations will not be able to carry on themselves and their effectiveness will be decreased ([8], [9]). In addition, good communication will lead children to increase their self-esteem and self-confidence [10]. Collaboration in learning help school children develop various skills such as thinking skills, self-management skills, oral communication skills, social-interaction skills, responsibility for each other and self-esteem [11].

The following information has been reached in Baker's study. Some predefined families were involved a little or not at all, some other families with high attendance were involved directly or indirectly in schools in different ways and at different levels. This way, many of the participating parents have been involved in many subjects and areas within the school, and some have declared that they participated not only in volunteering but also in developing their own skills. Families who volunteered at the school understood that it was useful for school and children, and 
that they helped teachers to do their jobs in a better way. Another subject in this study was school-family-teacher communication (conferences, conferences, telephone calls). These meetings had three forms.

1 Features to meet on a specific topic,

2 To hold meetings about ongoing teacher communication and the development of the child,

3 To organize regularly scheduled teacher-family conferences.

It was observed that these communications were discussed by parents. Thanks to that, it was stated that parents started to communicate not only with the students or teachers but also with the other parents. In this process, it was said that not all families were not at the same level of communication. Some did not attend regularly scheduled meetings. Some of the consequences of being involved in the education of children included: Some parents had contributed directly, sometimes indirectly or in different ways to their children's homework doing. It is also mentioned in the research that the parents wanted the teachers to provide feedback to them about the school and the work they do. Again, it was expressed in a survey that the parents were likely to delete the negative attitudes and behaviors of children that would prejudge their prejudices against other students with a range of mental and physical problems. With this project, families spent a large part of their day away from home, which is what they actually wanted for their children. In this way, the image of a warm, relevant, educational and supportive environment in which children are loved and appreciated has emerged. In addition, the parents wanted the teachers to individualize their children's education in order to allow them be more open to their own learning style. According to parents, the role of the teacher is to help all children, and no one can show more of their interest to their children on behalf of their own parents as much as themselves. As discussed above, some parents participate to draw attention to the problem between the school and their children. In such examples, participation was seen as a tool for solving the problem rather than a goal to achieve [12]. In a similar study by Li et al [13], it is argued that parent-child homework impacts student development and there is a positive relationship between parental involvement and child development in the context of migrant families. The organizational mechanism of promoting parents' participation in schooling should be improved as the students' development demands high-quality parent involvement [14].

In this study, it was aimed to increase the parents' contribution to the school, to see the problems related to the students and to take part in solution proposals, to increase the success of the school, to make common goals and to use the existing possibilities and to improve the sense of ownership of the parents about schools. For this purpose, with the application of the "Volunteer Guardianship Program", it was asked whether positive developments in terms of social, emotional and academics could be achieved for the students in school.

\section{Materials and Method}

Mixed quantitative and qualitative methods were used in the study. In the qualitative method, alongside human behaviors involved in the research with a flexible and holistic approach, the opinions and experiences of the individuals were of great importance [15], [16], [17], [18], [19]. Therefore, one tried to determine the views and experiences of the parents on the school.

\subsection{Research Instrument}

In the quantitative dimension of the study, "The Scale of Determining Relevant Views and Experiences" was used by the researcher to determine the views and experiences of the parents in relation to the school. The specified scale consists of 15 items. 1 of these items was specified open-ended, 3 were open-ended, 4 were yes-no questions and 7 were five point Likert scale. Also, before passing on to the work to be done in the schools, the necessary explanations were made to the parents about the purpose of the study after some discussions. Later on, the parents who agreed to voluntarily come to school were selected meticulously and the days they were supposed to be in the school were determined.

As a result of the research, the "Parent Conversion Scale" was used to see the changes in our parents' opinions and experiences. This scale consists of 23 items. 4 of the items are aimed at obtaining demographic information, 3 of them are open-ended, 5 are yes-no questions and 11 are Likert type.

The qualitative dimension of the research was established in the direction of findings obtained from the quantitative data. Thus; it was tried to determine whether there are any new changes to their previous views and experiences after the parents had been in school. For this reason, open-ended questions were included in the study. In addition to the scale, as open ended interview questions were qualitative data, a qualitative analysis was done. Open-ended questions provide the researcher with considerable flexibility in obtaining more detailed information on the subject [15].

This study supports both the quantitative and quantitative data; although the method of research considered is limited [18], as it only deals with the details of the research in terms of parents [20].

Many Likert-type items in the "Scale to Determine School Relationship Views and Experiences in the Parents" were scored as Very much (5), "Never" (1). The Cronbach Alpha internal consistency coefficient of this scale was found to be 0.88 . Depending on the alpha coefficient, the reliability of the scale was found to be $0.80 \leq \alpha$. The "Parent Conversion Scale" was scored as I strongly agree (5), I definitely do not agree (1). The Cronbach Alpha internal consistency coefficient of this scale was found to be 0.98 . Depending on the alpha coefficient, the reliability of the scale was found to be $0.89 \leq \alpha$. 


\subsection{Participants}

Hasan Tahsin Kırali Elementary School, Yakup Kalafatoğlu Elementary School, Ayşe Kırali Elementary School in Surmene County, Trabzon province, Turkey were selected as pilot schools and the study started after the necessary permissions were obtained. The research was completed in two academic years. During the first academic year (2014-2015), seminars were held to inform parents and raise their awareness. In the second academic year (2015-2016), parents who were to be voluntarily enrolled in the school were determined in advance and the "Scale for Determining Relationship Views and Experiences" was applied to them. At the end of the second academic year, "Parent Conversion Scale" was applied to evaluate the differences and the results of the project. A total of 240 children were employed in the implementation of this project. The data obtained by taking the frequency, percentage and arithmetic mean of the data obtained from both scales were analyzed. The results of the analysis showed that the parents' opinions changed positively as a result of this practice and they contributed more to the effectiveness of the school. For this reason, 3 schools were interviewed by the guidance services and evaluation reports on the changes in the school were also taken.

\section{Findings and Discussion}

During the 2014-2015 and 2015-2016 academic years; this study was carried out in Surmene Hasan Tahsin Kirali Primary School, Surmene Yakup Kalafatoglu Primary School and Surmene Ayşe Kirali Primary School, all located in the Surmene county, Trabzon province, in Turkey. A total of 240 parents, 80 parents from each school, contributed to the project.

In this study, "Parents' Relationships with and Experiences about School Determination Scale" was applied and the following findings were obtained. First, demographic information was provided. Gender, age, education, occupational status of the parents and also classes of students in the school were determined.

Table 1. Distributions of Legal Guardians according to Sex

\begin{tabular}{|c|c|c|}
\hline Gender of the participating parents & N & $\%$ \\
\hline Female & 156 & 65 \\
\hline Male & 84 & 35 \\
\hline
\end{tabular}

Table 2. Distribution of Parents According to Age Groups

\begin{tabular}{|c|c|c|}
\hline Age Group Ranges & N & $\%$ \\
\hline 20 to 30 years & 36 & 40 \\
\hline $31-40$ years & 96 & 40 \\
\hline $41-50$ years & 96 & 5 \\
\hline 51 years and over & 12 & 40 \\
\hline
\end{tabular}

The distribution of the parents according to educational status is as follows.

Table 3. Distribution of Legal Guardians According to Educational Status

\begin{tabular}{|c|c|c|c|}
\hline \multirow{4}{*}{ Female } & Education Level & N & \\
\cline { 2 - 4 } & Primary education & 41 & 19.28 \\
\cline { 2 - 4 } & Secondary education & 31 & 33.33 \\
\cline { 2 - 4 } & High school & 52 & 7.70 \\
\cline { 2 - 4 } & Associate Degree & 12 & 12,82 \\
\hline \multirow{3}{*}{ Male } & College & 20 & 19.05 \\
\cline { 2 - 4 } & Primary education & 16 & 16.67 \\
\cline { 2 - 4 } & Secondary education & 14 & 47.62 \\
\cline { 2 - 4 } & High school & 40 & 7.13 \\
\cline { 2 - 4 } & Associate Degree & 6 & 9.53 \\
\hline
\end{tabular}

The distributions of the parents according to their professional groups are as follows. 
Table 4. Distribution of Guardians According to Occupation Status

\begin{tabular}{|c|c|c|c|}
\hline \multirow{3}{*}{ Female } & Jobs & N & $\%$ \\
\cline { 2 - 4 } & Housewife & 109 & 69.90 \\
\cline { 2 - 4 } & Employees & 47 & 30.10 \\
\hline \multirow{3}{*}{ Male } & State Officer & 8 & 9.53 \\
\cline { 2 - 4 } & Private sector & 6 & 7.14 \\
\cline { 2 - 4 } & Self-employed and Tradesman & 70 & 83.33 \\
\hline
\end{tabular}

Table 5. Occupational Distributions of Guardians who are Workers

\begin{tabular}{|c|c|c|c|}
\hline \multirow{4}{*}{ Female } & $\begin{array}{c}\text { Occupation Distribution of } \\
\text { Employes }\end{array}$ & N & 14.90 \\
\cline { 2 - 4 } & Teacher & 7 & 10.63 \\
\cline { 2 - 4 } & State Officer & 52 & 8.52 \\
\cline { 2 - 4 } & Nurse & 4 & 8.51 \\
\cline { 2 - 4 } & Artisan & 4 & 6.38 \\
\cline { 2 - 4 } & Midwife & 3 & 6.38 \\
\cline { 2 - 4 } & Retired & 3 & 6.38 \\
\hline \multirow{5}{*}{ Male } & Salesman & 3 & 38.30 \\
\cline { 2 - 4 } & Other & 18. & 14.29 \\
\cline { 2 - 4 } & Teacher & 12 & 14.29 \\
\cline { 2 - 4 } & Self-employment & 12 & 10.71 \\
\hline & State Officer & 9 & 10.71 \\
\hline
\end{tabular}

Table 6. Which grade does your child attend in his/her school?

\begin{tabular}{|c|c|c|c|}
\hline & & $\mathrm{N}$ & \% \\
\cline { 2 - 4 } & 1st Grade & 63 & 26.25 \\
\cline { 2 - 4 } Which school does \\
\cline { 2 - 4 } your child read to school & 2nd Grade & 38 & 15.83 \\
\cline { 2 - 4 } & 3rd Grade & 35 & 14.59 \\
\cline { 2 - 4 } & 4th Grade & 32 & 13.33 \\
\cline { 2 - 4 } & 5th Grade & 21 & 8.75 \\
\cline { 2 - 4 } & 6th Grade & 30 & 12.5 \\
\hline
\end{tabular}

According to the findings above, it was observed that the women guardians participated more in their children's activities at schools. Among women, especially housewives were found to be more involved in these activities. It was found that parents between the ages of 30 and 50 were more involved in school activities. When we evaluate according to professional groups, we see that the parents who are teachers, participate more in these activities. In addition, we noticed that in the relationship between the guardians and schools, for first graders the concern or attention is higher, and the relationship of the parents to the schools is reduced as the students move to higher classes. This opinion of ours supports the statistical data that the Ministry of National Education (MNE) had previously collected. According to the data obtained from the official website of the Ministry of National Education, the participation rate of the parents to the parental meetings in the schools was shown as $17 \%$ [21].

The data obtained aside from the demographic information are as follows. 
Table 7. How often do you come to the school?

\begin{tabular}{|c|c|c|c|}
\hline \multirow{4}{*}{$\begin{array}{c}* \\
\text { Q-1- How often do you want to }\end{array}$} & N & $\%$ \\
\cline { 2 - 4 } go to the school? & For each PTA meeting & 94 & 39.17 \\
\cline { 2 - 4 } & Once in each term & 65 & 27.08 \\
\cline { 2 - 4 } & Once a month & 46 & 19.17 \\
\cline { 2 - 4 } & I never go & 14 & 5.83 \\
\hline
\end{tabular}

Table 8. For what do you usually come to the school?

\begin{tabular}{|c|c|c|c|}
\hline \multirow{6}{*}{$\begin{array}{l}\text { Q-2-What for do you usually go } \\
\text { to the school? }\end{array}$} & & $\mathrm{N}$ & $\%$ \\
\hline & To learn my student's grades & 118 & 49.17 \\
\hline & To get help from teachers about how to handle students & 50 & 20.83 \\
\hline & To communicate problems with other students & 28 & 11.66 \\
\hline & To solve problems that my student is experiencing & 25 & 10.42 \\
\hline & Other & 19 & 7.92 \\
\hline
\end{tabular}

Table 9. If you are aware, which problems of the school draw your interest?

\begin{tabular}{|c|c|c|c|}
\hline \multirow{7}{*}{$\begin{array}{l}\text { Q-4- If yes, what problems of the } \\
\text { school attract your interest? }\end{array}$} & & $\mathrm{N}$ & $\%$ \\
\hline & Number of students sent to a higher education institution & 88 & 36.67 \\
\hline & Awareness about the education given to the province and the district & 64 & 26.67 \\
\hline & Social and cultural activities & 31 & 12.92 \\
\hline & Disciplinary events in the school & 22 & 9.16 \\
\hline & Teacher success & 21 & 8.75 \\
\hline & Other & 14 & 5.83 \\
\hline
\end{tabular}

Table 10. If your answer is yes, how did you contribute?

\begin{tabular}{|c|c|c|c|}
\hline \multirow{6}{*}{$\begin{array}{c}\text { Q-6- If yes, how did you } \\
\text { contribute? (The answer to the fifth } \\
\text { question is based on the answers of } 65 \\
\text { people who answered yes.) }\end{array}$} & & $\mathrm{N}$ & $\%$ \\
\hline & I found the material support & 22 & 33.85 \\
\hline & I contributed to social activities & 18 & 27.69 \\
\hline & I have been in discussions with the families of disciplined children & 10 & 15.38 \\
\hline & I worked in the parent-teacher association (PTA) & 8 & 12.31 \\
\hline & Other & 7 & 10.77 \\
\hline
\end{tabular}

Table 11. Do you have a project that you want your child to do? If yes, we are.

\begin{tabular}{|c|c|c|c|}
\hline \multirow{5}{*}{$\begin{array}{l}\text { Q-6 - Do you have a project that } \\
\text { you want to do for your child? If yes, } \\
\text { write it down. }\end{array}$} & & $\mathbf{N}$ & $\%$ \\
\hline & "I think these projects should be determined by the school we can't know" Sayers & 97 & 40.42 \\
\hline & "Some work should be done to determine children's abilities" Sayers & 87 & 36.25 \\
\hline & "Laboratory studies should be increased" Sayers & 35 & 14.58 \\
\hline & "I do not have a project" Sayers & 21 & 8.75 \\
\hline
\end{tabular}




\section{Q-3-Are you aware of the school's problems?}

It was found that $16.25 \%$ (39 people) of the participants were not informed about school problems at all, 38.33\% (92 people) were informed just a bit about school problems, and $28.33 \%$ (68 people) were moderately informed, $12.92 \%$ (31 people) were more aware of the school's problems and $04.17 \%$ (10 people) were frequently updated about school problems.

Q-5- Have you contributed to the solving of any problem of the school in which your child was implicated?

Of those surveyed, $27.08 \%$ (65 people answered yes) said that they've contributed to resolve at least to a problem at the school, whereas $72.92 \%$ of them (175 people answered no) said that they've never contributed to the solving of any problems at school.

Q-7-Do you believe that parents who have students in our school participate sufficiently in the meetings held in the school?

Of the respondents, $22.5 \%$ (54 people) had never attended any meeting, 49\% (110 people) had a little participation, $20 \%$ (48 people) had a moderate level of participation, $6 \%$ (15 people) participated much and $2 \%$ (5 people) stated that they frequently attended the meetings.

Q-8-Have you ever attended social activities organized at school?

It was stated that $7.5 \%$ (18 people, Yes) participated in the social activities organized in the school and 92.5\% (222 persons, No) did not participate in the social activities organized in the school.

Q-9-Would you accept the tasks that will be given to you by the administration in the social activities to be held in the school?

$51.67 \%$ of the survey participants (124 persons, Yes) would accept the duties given by the administration in the social activities to be organized in the school. $48.33 \%$ (116 people, No.) said that they would not accept the duties to be given to them by the administration in case of social activities to be organized in the school.

Q-10- Are you able to report the negativities you have seen in and outside the school to the relevant persons?

Of the participants in the survey, $15.83 \%$ (38 people) answered that they had never reported to relevant people any problems they had seen in and out of the school, 26.67\% (64 people) said that they had reported a few negativity seen in and out of school, $36.67 \%$ ( 88 people) mentioned that they had moderately reported to relevant people negativities seen in and out of school, $17.92 \%$ (43 people) said that they had reported quite often to relevant people what they've seen in and out of the school, and $2.91 \%$ (7 persons) answered that they had reported frequently to the relevant people problems they had seen in and out of the school.

Q-11-Are you willing to participate voluntarily in the courses organized to pass on your experiences to our children in school for them to improve their skills?

$60 \%$ of the survey participants (144 people, Yes) are willing to volunteer for the courses in order to improve the skills of our children in the school, sharing with them their experiences in terms of, 40\% (96 people, No.) said they would not voluntarily participate in the courses organized for them in order to improve the skills of our children at school.

Q-12-Do you want help from experts in the schools to resolve conflicts arising among your children?

Of the participants in the survey, $15 \%$ (36 people) said that they did not want any help from experts for their children to resolve conflicts among themselves in school, $18.75 \%$ (45 people) answered that that they are less likely to ask for help from experts for their children to resolve conflicts among themselves in school, $24.17 \%$ (58 people) said that that they are moderately willing to ask for help from experts for their children to resolve conflicts among themselves in school, and $23.75 \%$ (57 people) said that that they wanted more help from experts for their children to resolve conflicts among themselves in school. $18.33 \%$ (44 people) stated that they frequently asked for help from experts for their children to resolve conflicts among themselves in school.

Q-13-Are you willing to discuss with your children about or let them share with you what they live in school?

It was found that $6.25 \%$ of the participants ( 15 people) did not share anything with their children about what they are experiencing at school, $18.33 \%$ (44 people) shared only a few things with their children about what they are facing at school, $36.25 \%$ ( 87 people) shared at a medium-level with their children about what they are facing at school, $38.33 \%$ (92 people) shared much with their children about what they are facing at school, $0.84 \%$ ( 2 persons) shared very often. with their children about what they are facing at school.

Q-14- Are you trying to complete the missing aspects of your school and the materials that are important for education and training?

It was found that $26.67 \%$ of the participants (64 people) had not made any effort to complete the school's important materials, $32.08 \%$ of them (77 people) made a slight effort to complete the school's important materials, $27.08 \%(65$ people) made a moderate effort to complete the school's important materials, $10 \%$ (24 people) had made a lot of efforts to complete school materials thought to be incomplete or lacking vital information for education, $4.17 \%$ (10 people said that they had made too much efforts to complete the material that they found lacking and materials important for education and training in the school.

Q-15-Are you involved in any initiatives or activities that will provide coordination with all the parents in order to improve the sense of ownership in our school?

It was found that $10.42 \%$ ( 25 people) of the survey participants had never been involved in any initiatives or activities that will provide all the parents with the coordination necessary to improve their sense of ownership in schools, $19.58 \%$ (47 people) of them had little or no involvement in activities or activities that will provide all the parents with the coordination necessary to improve their 
sense of ownership in schools, $26.67 \%$ (64 people) were moderately involved in initiatives or activities that would provide all the parents with the coordination necessary to improve their sense of ownership in schools, $32.5 \%$ (78 people) stated they had much been involved in activities that would provide all the parents with the coordination necessary to improve their sense of ownership in schools and $14.83 \%$ ( 26 people) of them indicated that they were very much implicated in activities that would provide all the parents with the coordination necessary to improve their sense of ownership in schools.

The assessments showed that parents or legal guardians do not go to the schools to which they've sent (registered) their children and even when they go to the school, they generally go for the education-oriented success evaluations, that they are not sufficiently informed about the school's problems and the school does not participate enough in activities related to the solving of school's problems.

It was also determined that they did not participate sufficiently in the school's meetings, that they mostly remained unresponsive or were indifferent to the school's security problems, that they did not participate in social activities and they were not adequately engaged in these activities in their own capacity, that they did not adequately contribute to the completion activities of the missing materials of the school and, above all, that they did not participate in common activities to improve the sense of ownership.

Since the first five questions are the same as the demographic information in the other survey, they have not been shown here again in order to avoid repetition.

Q-7 Would you like that student houses be visited by your school (for training purposes)?

Of those surveyed $77.5 \%$ answered (186 people said Yes) that they agree with the school visiting a student's house (for educational purposes), $22.5 \%$ on the other hand answered (54 people said No) that student houses shouldn't be visited by the school (for training purposes). People who disagreed are thought to have some sociological reasons.

Q-8- Have you ever participated in such a program?

Of those surveyed, $5 \%$ (12 people said yes) said they had participated in such a program before, $95 \%$ (226 people said No) said that they hadn't ever participated in such a program.

S-9 Did people in charge of this program give you any information about it?

All of the participants ( 240 people) said that information was given prior to the program.

Q-10 Do you believe that this program provides enough time to get to know the school?

All of the participants (240 people) said the program duration would be enough time.

Q-11 If you want this duration to be increased, how long should it actually be? Please write your suggestion in terms of days.
All the participants in this study (240 people) said they would like volunteer guardians to be selected before school starts each year because this program helped them to develop some skills. Therefore, they replied that this program needs to be continuing throughout the whole the educationteaching periods.

Q-12- I believe the application of this program in the school is beneficial.

$92.92 \%$ of the participants in this program said that (223 people) they absolutely agreed that this application in schools is useful, while $07.08 \%$ (47 people) stated that they agreed that this program is useful in schools.

Q-13- I would like this program to continue to be widespread.

$81.67 \%$ of those surveyed (196 people) strongly agree to continue expanding this program in the school, $18.33 \%$ of them (47 people) stated that they agree to continue expanding this program in the school.

Q-14- I believe that this program will facilitate the education process of our children.

$89.17 \%$ of those polled (214 people) answered that they strongly believed that this program would certainly facilitate the education process in our children, whereas $10.83 \%$ of them (26 people) said they agreed this program would facilitate the education process of our children.

Q-15 Your presence in school was well welcomed by children.

$76.25 \%$ of the participants (183 people) answered that children strongly agreed with their presence in school and welcomed the initiative, $21.67 \%$ of them (52 people) said that children agreed with their presence in school and welcomed the initiative, $2.08 \%$ (5 people) said that children seemed undecided when it came to answer whether or not agreed with their presence in school and welcomed the initiative.

Q-16- I would also like to see our other parents who have students in our schools involved in such a program.

$96.25 \%$ of the respondents (231 people) strongly agreed to include in such a program other parents whose children are students at the same school, $3.33 \%$ ( 8 people) agreed to include in such a program other parents whose children are students at the same school, $0.42 \%$ ( 1 person) were uncertain regarding the fact that whether they agreed to include in such a program other parents whose children are students at the same school.

Q-17 Did you transmit your suggestions to the school administrators after the program?

All the participants in this study (240 people said Yes) replied that after the program they had forwarded their suggestions to the school administrators.

Q-18- I believe that the suggestions that came to my mind as a result of the experience I acquired in this program, after being expressed by me to the school administrators will be 
considered by them.

$51.25 \%$ of those surveyed, (123 people) answered that they strongly believed that the suggestions that came to their mind as a result of the experience acquired in this program, after being expressed to the school administrators would certainly be considered by them. $21.67 \%$ of them ( 52 people) answered that they believed that the suggestions that came to their mind as a result of the experience acquired in this program, after being expressed to the school administrators would be considered by them. $18.75 \%$ (45 people) answered that they were uncertain if the suggestions that came to their mind as a result of the experience acquired in this program, after being expressed to the school administrators would be considered by them., $8.33 \%$ of them ( 20 people) replied that they thought their suggestions after being expressed to the school administrators would not actually be considered by them.

Q-19- Thanks to this program, I felt better how school is an active element and I established a better identification with school.

Of the surveyed people, $74.58 \%$ (179 people) strongly agreed with the idea that thanks to this program, they felt better how school is an active element and established a better identification with school. $22.08 \%$ of them (53 people) agreed with the idea that thanks to this program, they felt better how school is an active element and established a better identification with school, $3.34 \%$ of the participants ( 8 people) were uncertain whether or not, thanks to this program, they felt better how school is an active element and established a better identification with school.

Q-20- From now on, I know the school's problem, and I believe I will provide a more selfless contribution to our teachers and school managers in order to solve these problems.

$64.17 \%$ of the participants in the survey (154 people) strongly agreed with the fact that from now on, they know the school's problem, and believe they would provide a more selfless contribution to teachers and school managers in order to solve these problems, $30.42 \%$ of them ( 73 people) agreed with the fact that from now on, they knew the school's problem, and believed they would provide a more selfless contribution to teachers and school managers in order to solve these problems, $5.41 \%$ (13 people), were uncertain about the fact that from now on, they know the school's problem, and believe they would provide a more selfless contribution to teachers and school managers in order to solve these problems.

Q-21- I believe that this program will contribute to social improvements both of my and my children's life.

$56.77 \%$ of the respondents (136 people) strongly agreed that this program will contribute to social improvements both of their own and their children's life. $38.75 \%$ of them (93 people) believed that this program would contribute to social improvements both of their own and their children's life, $4.17 \%$ (10 people) said they were uncertain that that this program would contribute to social improvements both of their own and their children's life, $0.41 \%$ ( 1 person) said they did not agree that that this program would contribute to social improvements both of their own and their children's life.

S-22- I believe that with the implementation of this program families will identify to the school.

$87.08 \%$ of the respondents (209 people) strongly believed that with the implementation of this program families will identify to the school, $10.42 \%$ ( 25 people) agreed that with the implementation of this program families will identify to the school, $2.5 \%$ (6 people) said they were uncertain whether with the implementation of this program families will identify to the school.

Q-23- I want this program to be continued by providing the participation of all the parents who have their children in the school.

$90.42 \%$ of those surveyed (217 people) strongly agreed that this program needed to be continued by providing the participation of all the parents who have their children in the school, $9.17 \%$ of them (22 people) agreed that this program needed to be continued by providing the participation of all the parents who have their children in the school, $0.41 \%$ of them (1 person) were uncertain about this issue.

When we take a closer look at these results, we can easily notice that there was an increase in positive behaviors and a decrease in negative behaviors both in the schools attended by pupils of the selected guardians and themselves. It has also been found out that whereas the school visits rates of guardians were very low in the beginning, this rate increased, and the problems of the school were more clearly defined and solution-oriented behaviors were displayed when it came to find some solution to these problems. It has also been determined that some of the participating parents had volunteered for extracurricular activities. During the implementation of the project, it has been requested from the teachers responsible for guidance and counseling services of the school, to observe and to write down their observations as a report which shall then be presented to our attention.

The results obtained from the reports prepared in this context are listed as follows.

- It has been stated that with the presence of the parents in the school, there is a positive increase in the behaviors of the students, especially a positive increase in the children's self-confidence.

- The problems at the entrance and exit of the school were reduced,

- With the contributions of the parents in extracurricular activities the effectiveness of the pupils increased,

- The sense of ownership in school increased and the willingness of the guardians to participate in finding solutions to the school's problems also increased,

- There was an increase in the contributions of the parents in the activities that would contribute to 
the development of the children, especially in the educational activities to be done at home,

- There was an increase in the number of school visits by the other parents and a constant increase of implication in the effort to make the school more effective by the parents who used to come only to check the academic success of their child in the class,

- There was a decrease of $30-35 \%$ in disciplinary offenses as compared to the previous year

- It has been determined that the parents detect the negativities outside the school more quickly and they contacted the authorities in order to overcome these problems.

\section{Conclusions}

At the end of this study; it was observed that the 'Volunteer Parent on call (Guardian) Project' not only facilitated the work of teachers in schools, but also ensured the interaction of students with their parents both inside and outside the school. Through this project parents are aware of their children's activities and behaviors at school and around the school, can observe which kind of people and environment the child is faced to. Even though some parents didn't contribute to the project due to working conditions, most of them played an active role in the execution of the project.

We found out from the data that the school visits rates of guardians were very low in the beginning, but after the implementation of the program this rate increased, and the problems of the school were more clearly defined and solution-oriented behaviors were displayed when it came to find some solution to these problems.

Parents generally had a positive approach to the project. Even though in the early stages of project implementation, some parents and teachers mentioned some concerns, these concerns disappeared once the project was implemented. Because with the implementation of the project the followings were observed: a rise in the level of cohesion among students-teachers-parents, the effectiveness in the school and its students' activities, the emergence of many positive behaviors and the preclusion of some negative things as a result of the examination of reports written by guide teachers.

Undoubtedly, students may experience here some repressed feelings. Because, in the presence of their parents, students tend to move with more caution at the school, as far as possible they try to avoid negative behaviors and begin to exhibit exemplary behaviors.

As a result, these are the findings of a comparison of the overall situation in the school before and after the implementation of the project. The percentage of negative behaviors display at school for students before the project was high, whereas after the application of the project, in the report given by the teacher responsible for the school's guidance, disciplinary offenses showed a decrease of $30-35 \%$ as compared to the previous year and that there was an increase in student determination to display their positive behaviors. With parents coming to the school, there have been positive developments and an increased effectiveness of the school.

\section{Suggestions}

- The proliferation of these kinds of studies should be promoted, that's why the Ministry of National Education and related organizations should support both this and other similar studies.

- Activities which promote the integration of the guardians in the school life should be increased.

- The adverse effects of school entrance and exit should be reduced by promoting the communication between the guardians and the school officials.

- A team of volunteer traffic police should be created from among the guardians in order to prevent the negative effect of the busy traffic nearby the school entrance and exit.

- The school executive should receive help from the guardians for the organization of extracurricular activities.

- Guardians should be asked for help in order to open certain courses (such as music, drawing etc.)

- New arrangements should be made for the arrival of the guardians

- The rate at which the guardians visit the school should be increased after informing them.

- Guardians should also be trained in order to complete aspects that they are inadequate in or in which they have some deficiencies.

- The school should be assessed in terms of the inadequacies and contributions should be provided from the guardians in eliminating the shortcomings.

- Especially skilled parents should be assisted in performing their abilities.

\section{REFERENCES}

[1] Li, Y., Li, Y., Morgan, L., and Li, J. (2016). Calling for Children Friendly Community Life: Voices of Children and Parents from China. Chapter 12, Community Engagement Program Implementation and Teacher Preparation for 21st Century Education, Ed: Cathryn Crosby Frederick Brockmeier. IGI Global, USA.

[2] Li, J., Wang, P. and Chen, Z. (2013). Student Developmental Needs Based Parent Partnership: A Case Study of Qilun Elementary School in Minhang District, Shanghai. 
International Journal about Parents in Education, Vol. 7, No. 2, 91-99.

[3] Acıkalin, A. Turan, S., (2011), Okullarda Etkili Iletişim, Pegem Publishing, Istanbul, p.11.

[4] West, M. (2000), Increasing Parent Involvement for Student Motivation, Improve Reading Grades in Middle School, University of New England, p.1-6.

[5] Kayalar, F. (2016). Views of Teachers on the Benefits of After-School Programs and Summer Programs in terms of Social Emotional Learning. Merit Research Journal of Education and Review, Vol. 4(2) pp. 006-013, February, 2016

[6] Epstein, Joyce L.; Sanders, Mavis G.; Simon, Beth S.; Salinas, Karen Clark; Jansorn, Natalie Rodriguez; Van Voorhis, Frances L., (2002), School, Family and Community Partnerships: Your Handbook for Action, Corwin Press, Inc., p.107-112.

[7] Steven R. Hara and Daniel J. Burke, (1998), "Parent Involvement: The Key to Improved Student Achievement", The School Community Journal, Vol.8, No.2, Fall/Winter, p.9-17.

[8] Ergin, A., (2012), Eğitimde Etkili İletişim, p.197.Anı Publishing, Ankara.

[9] Kaya, A., (2012), Kişilerarası İlişkiler ve Etkili İletişim, p.5, .Pegem Akademi Yayıncılık, Ankara.

[10] Whirter, J. Mc and Acar,N. V. , (2000), Ergen ve Çocukla İletişim, p.75.US-A Publishing, Ankara.

[11] Güler Arı, T. (2016) Study into the Views of the Students Learning Turkish as a Foreign Language over Collaborative Learning in Language Courses. Education Research Journal (International Research Journal ISSN 2026-6332), Vol. 6(10), 188-192, October 2016.
[12] Baker, Amy J. (1997), "Improving Parent Involvement Programs and Practice: A Qualitative Study of Parent Perceptions", The School Community Journal, Vol. 7, No. 1, Spring/Summer, p.127-153.

[13] Li, J., Li, Y., and Yin, T. (2015). Does Parental Involvement Contribute to Students' Development? The Parent-Child Homework Experiment at a Shanghai Migrant School. International Journal about Parents in Education, Vol. 9, No. $1,1-9$

[14] Gu, H., Yin, L. and Li, J. (2015). Making Homework a Catalyst of Teacher-Parents-Children's Collaboration: A Teacher Research Study from an Elementary School in China. International Journal about Parents in Education, Vol. 9, No. 1, 47-65.

[15] Yıldırım, A., ve Simşek, H. (2005). Sosyal Bilimlerde Nitel Araştırma Yöntemleri, p.14,.Seçkin Publishing, Ankara.

[16] Türnüklü, A. (2001). Eğitimbilim Alanında Aynı Araştırma Sorusunu Yanıtlamak için Farklı Araștırma Tekniklerinin Birlikte Kullanılması, Eğitim ve Bilim, 26(120), p. 8-13.

[17] McMillan, J.H. and Schumacher, S. (2006) Research in Education: Evidence-Based Inquiry (Sixth Edition), p.7. Pearson, London.

[18] Creswell, J. W. (2003). Research design: A qualitative, quantitative and mixed method approaches. Thousand Oaks, CA: Sage Publications, Inc.

[19] Mertens, D. M. (2005). Research and evaluation in education and psychology: Integrating diversity with quantitative, qualitative, and mixed methods (2nd ed.). Thousand Oaks, CA: Sage.

[20] Tashakkori, A., and Teddlie, C. (1998). Mixed methodology: Combining qualitative and quantitative approaches. Sage Publications, London.

[21] M.E.B. gov.tr. Erişim Tarihi: 30.12. 2015. 